\title{
Research Progress of ATGs Involved in Plant Immunity and NPR1 Metabolism
}

\author{
Shuqin Huang ${ }^{1,2,3}\left(\mathbb{D}\right.$, Baihong Zhang ${ }^{1,2,3}$ and Wenli Chen $1,2,3, * \mathbb{D}$ \\ 1 MOE Key Laboratory of Laser Life Science, Institute of Laser Life Science, College of Biophotonics, \\ South China Normal University, Guangzhou 510631, China; huangshuqin@m.scnu.edu.cn (S.H.); \\ zhangbyhome@126.com (B.Z.) \\ 2 Guangdong Provincial Key Laboratory of Laser Life Science, College of Biophotonics, \\ South China Normal University, Guangzhou 510631, China \\ 3 Guangzhou Key Laboratory of Spectral Analysis and Functional Probes, College of Biophotonics, \\ South China Normal University, Guangzhou 510631, China \\ * Correspondence: chenwl@scnu.edu.cn; Tel.: +86-20-8521-1436-8611
}

Citation: Huang, S.; Zhang, B.; Chen, W. Research Progress of ATGs Involved in Plant Immunity and NPR1 Metabolism. Int. J. Mol. Sci. 2021, 22, 12093. https://doi.org/ $10.3390 /$ ijms222212093

Academic Editors: Sławomir Borek and Małgorzata Pietrowska-Borek

Received: 26 September 2021 Accepted: 4 November 2021 Published: 9 November 2021

Publisher's Note: MDPI stays neutral with regard to jurisdictional claims in published maps and institutional affiliations.

Copyright: (c) 2021 by the authors. Licensee MDPI, Basel, Switzerland. This article is an open access article distributed under the terms and conditions of the Creative Commons Attribution (CC BY) license (https:// creativecommons.org/licenses/by/ $4.0 /)$.

\begin{abstract}
Autophagy is an important pathway of degrading excess and abnormal proteins and organelles through their engulfment into autophagosomes that subsequently fuse with the vacuole. Autophagy-related genes (ATGs) are essential for the formation of autophagosomes. To date, about 35 ATGs have been identified in Arabidopsis, which are involved in the occurrence and regulation of autophagy. Among these, 17 proteins are related to resistance against plant pathogens. The transcription coactivator non-expressor of pathogenesis-related genes 1 (NPR1) is involved in innate immunity and acquired resistance in plants, which regulates most salicylic acid (SA)-responsive genes. This paper mainly summarizes the role of ATGs and NPR1 in plant immunity and the advancement of research on ATGs in NPR1 metabolism, providing a new idea for exploring the relationship between ATGs and NPR1.
\end{abstract}

Keywords: Arabidopsis; autophagy; NPR1; plant immunity

\section{Plant Immunity}

\subsection{PTI and ETI}

Plants have evolved a complex immune system to combat the threat from pathogenic microorganisms in nature, including innate and acquired immunity [1-3]. It possesses two innate immune defense lines that enable cell-autonomous defense responses upon pathogen infection. For the first line of innate immunity, plant cell surface-localized pattern recognition receptors (PRRs) recognize microbe associated molecular pattern (MAMP) or pathogen-associated molecular pattern (PAMP) to activate pathogen-associated molecular pattern triggered immunity (PAMP-triggered immunity, PTI) [4-6]. However, some plant pathogens can produce effectors to inhibit PTI. The other immune defense line is activated by the proteins encoded by resistance genes ( $R$ genes), these proteins can directly or indirectly recognize the effectors secreted by pathogenic microorganisms. This process is known as effector-triggered immunity (ETI) that usually leads to local programmed cell death (PCD) called hypersensitive response (HR) $[7,8] . R$ genes are highly expressed during pathogen infection, most of them encode the nucleotide-binding (NB) domain and Leu-rich repeat (LRR)-containing (NLR) proteins that recognize pathogen effectors and activate ETI, which usually leads to the accumulation of reactive oxygen species (ROS) and HR. Based on the N-terminal structures, NLR proteins can be classified into two categories. TIR-NLR (TNLs) contain the toll/interlcukin-1-reccptor (TIR) region and CC-NLR (CNLs) contain coiled coil (CC) domain [9-15].

The latest studies have clarified the new mechanism of crosstalk and cooperation between PTI and ETI, they activate many pathways that are closely related to each other 
and activate plant immune signaling pathways [16-18]. ETI enhances PTI responses, including ROS production, callose deposition, and upregulation of gene expression [16]. In addition, ETI-induced HR-PCD is enhanced by PTI [16]. More importantly, knocking out of key genes in the PTI pathway inhibits the ETI. In PRRs/co-receptor Arabidopsis mutants, fls2/efr/cerk1 (fec) and bak1/bkk1/cerk1 (bbc) mutants, ETI induced by Pst DC3000 (avrRpt2) was severely impaired $[17,18]$. It indicates that activation of ETI requires PTI involvement, this finding has major implications on future plant immunity studies.

\section{2. $S A R$}

Plant system acquired resistance (SAR) can be activated by local defense response, which emits chemical signals to alert neighboring cells and tissues and protect the whole organism [19-23]. Thus, it enables the plant to activate defense responses more quickly, strongly, and effectively when subsequently challenged by pathogens. This requires strict and precise regulation of plant hormones, metabolites, and proteins [24-28]. SAR activation is associated with the accumulation of salicylic acid (SA) and the induction of pathogenesis-related (PR) genes [29-31]. Recent studies have shown that pipecolic acid (Pip) and glycerol-3-phosphate (G3P) stimulate each other's biosynthesis and act together to trigger intracellular SAR and the emission of plant-to-plant (PTP) cues [32,33].

\section{ATGs Involved in Plant Resistance to Pathogens}

Autophagy is an evolutionary conserved intracellular regulatory mechanism, involving the degradation and recycling of intracellular proteins, metabolites, and organelles. One of its main characteristics is the formation of double-membrane vesicles, known as autophagosomes, which engulf a portion of cytoplasm and transport it into vacuoles for degradation [34-37]. More than 40 known autophagy-related genes (ATGs) that strictly regulate this membrane trafficking process have been identified in yeast [38]. In Arabidopsis, many genes with sequence similarity to the yeast ATGs have been identified. Current information from Arabidopsis database TAIR (https: / /www.arabidopsis.org/, 26 September 2021) and related literature showed that about 35 ATGs have been identified. Except for ATG14/29/31, other homologous genes of ATGs have been found in yeast [39]. The evolutionary process of autophagy is mainly divided into four steps: (1) ATG1-ATG13 complex and target of rapamycin (TOR) jointly induce autophagy. (2) ATG9 and phosphoinositide-3kinase (PI3Ks) complex containing ATG6, ATG14, vacuolar protein sorting 15 (VPS15), and VPS34, participate in protein sorting and promote vesicle expansion. (3) Two ubiquitin-like conjugation systems, ATG5-ATG12 and ATG8-phosphatidyl ethanolamine (ATG8-PE) systems, induce the formation of autophagosomes. (4) The fusion of mature autophagosomes with the vacuole $[35,36,40-43]$.

In recent years, great progress has been made in the identification of ATGs and the study of autophagy pathways. Some of these gene knockout mutations revealed the physiological role of autophagy in nutritional stress (nitrogen and carbon deficiency) and senescence [44-46]. In addition, more and more studies have shown that autophagy is also involved in plant immune response [47-51]. Autophagy plays a role in promoting and inhibiting pathogens in host-pathogen interactions. Hosts can induce or inhibit plant autophagy during pathogen infection, which is beneficial to resist pathogen invasion [52]. A recent study revealed the interaction between different ATGs and different pathogen effectors. Researchers found that ATG8 interacted with several effectors, while HrpZ1 targeted ATG8 to enhance autophagy levels and increase the virulence of Pto DC3000 hrcC, HopF3 targeted ATG8 to suppress autophagy. Although the interactions between ATG1, ATG7, ATG12, and several effectors were found in this study, the exact mechanism of these interactions in plant disease resistance is unclear [52]. Some of ATGs knockout mutations exhibited enhanced susceptibility to pathogen infection, such as atg2, atg 5 , atg6, atg7, atg9, atg10, and atg18 [13,53-60]. While atg2 mutants displayed less HR-PCD and ATG4, ATG5 inhibited the occurrence of HR-PCD, ATG6 antisense plants displayed enhanced HR-PCD during pathogen infection [53-59,61]. A recent study reported that 
phosphorylation modification of ATG18a suppressed autophagosome formation during pathogen infection, resulting in compromised plant resistance, which provides evidence for the involvement of autophagy in plant immune regulation [62]. Here, we summarize the interaction between bacteria, fungal effectors, and ATGs as well as the role of autophagy in HR-PCD and resistance regulation (Table 1).

Table 1. ATGs (autophagy-related genes) in Arabidopsis participate in plant disease resistance.

\begin{tabular}{|c|c|c|c|}
\hline Gene & Protein & Functions & References \\
\hline AT3G61960 & ATG1a & $\begin{array}{c}\text { Interacting with AvrRps4-Pph, AvrPtoB-Pto, HopY1-Pto, Rbp001, } \\
\text { Rbp002, Rbp005, Urf004, Urf010, Urf012. }\end{array}$ & [52] \\
\hline AT3G19190 & ATG2 & $\begin{array}{c}\text { Atg } 2 \text { mutants displayed enhanced disease resistance to powdery } \\
\text { mildew, exhibited enhanced susceptibility upon } D \text {. dadantii infection. } \\
\text { Less HR cell death in atg } 2 \text { mutants upon } \\
\text { Pst DC } 3000 / \text { avrRpm } 1 \text { infection. }\end{array}$ & [53-55] \\
\hline AT2G44140 & ATG4a & ATG4 inhibited the occurrence of HR & {$[61]$} \\
\hline AT3G59950 & ATG4b & during Psm ES4326/AvrRpt2 infection. & [61] \\
\hline AT5G17290 & ATG5 & $\begin{array}{c}\text { Atg } 5 \text { mutants displayed enhanced susceptibility to Alternaria } \\
\text { brassicicola, Botrytis cinerea, and Plectosphaerella cucumerina. } \\
\text { ATG5 inhibits the growth of Pst DC } 3000 \text { or Pst DC } 3000 \text { containing } \\
\text { avirulent factors (Pst-avrB, Pst-avrRps4, Pst-avrRpm1) at the early } \\
\text { stage of infection, which is necessary to limit PCD } \\
\text { induced by P. syringae. }\end{array}$ & {$[55,57-59]$} \\
\hline AT3G61710 & ATG6 & $\begin{array}{c}\text { ATG6 antisense plants displayed enhanced HR cell death when } \\
\text { infected with virulent } P \text { st DC3000 or avirulent Pst DC3000/avrRpm1. } \\
\text { ATG7 interacts with HrpZ1-Psy. }\end{array}$ & [56] \\
\hline AT5G45900 & ATG7 & $\begin{array}{c}\text { Atg7 mutants displayed enhanced susceptibility to Alternaria } \\
\text { brassicicola, Botrytis cinerea, and avirulent Pto DC3000/AvrRpm1 or Pto } \\
\text { DC } 3000 / \text { AvrRps4. }\end{array}$ & {$[13,52,58-60]$} \\
\hline AT4G21980 & ATG8a & $\begin{array}{l}\text { Interacting with AvrPto, HopF3-Pph, HopY1-Pto, HrpZ1-Pph, Rbp001, } \\
\text { Rbp002, Rbp003, Urf003, Urf004. HrpZ1 and HopF3 target ATG8 to } \\
\text { enhance and suppress autophagy, respectively.Overexpressing } \\
\text { ATG8a enhances plant tolerance to D. dadantii. }\end{array}$ & {$[52,55]$} \\
\hline AT4G04620 & ATG8b & & \\
\hline AT2G05630 & ATG8d & Interacting with HrpZ1. HrpZ1 enhances autophagy levels, & {$[52]$} \\
\hline AT3G60640 & ATG8g & increasing the virulence of Pto DC3000 hrcC. & [52] \\
\hline AT3G06420 & ATG8h & & \\
\hline AT4G16520 & ATG8f & $\begin{array}{c}\text { Interacting with AvrPtoB-Pto, HopF3-Pph, HopY1-Pto, HrpZ1-Pph, } \\
\text { Rbp001, Urf004. HrpZ1 and HopF3 target ATG8 to enhance and } \\
\text { suppress autophagy, respectively. }\end{array}$ & [52] \\
\hline AT3G15580 & ATG8i & $\begin{array}{c}\text { Interacting with AvrB2-Pph, AvrB3-Psy, AvrPto-Pto, HopAQ1-Pto, } \\
\text { HopO1-2-Pto, HopQ1-2-Pto, HopX1-Pto, HopY1-Pto, HrpZ1-Pph, } \\
\text { HrpZ1-Psy, Rbp001, Rbp002, Rbp005, Urf004, Urf012. HrpZ1 } \\
\text { enhances autophagy levels, increasing the virulence of } \\
\text { Pto DC3000 hrcC. }\end{array}$ & [52] \\
\hline AT2G31260 & ATG9 & $\begin{array}{c}\text { Atg9 mutants displayed enhanced susceptibility to avirulent Pto } \\
\text { DC3000/AvrRpm1 or Pto DC3000/AvrRps4. }\end{array}$ & {$[60]$} \\
\hline AT3G07525 & ATG10 & $\begin{array}{c}\text { Genetic inactivation of } A T G 10 \text { resulted in enhanced susceptibility to } \\
\text { Alternaria brassicicola and Plectosphaerella cucumerina, atg10 mutants } \\
\text { showed reduced bacterial growth rates when } \\
\text { infected with Pto DC } 3000 .\end{array}$ & {$[55,59]$} \\
\hline $\begin{array}{l}\text { AT1G54210 } \\
\text { AT3G13970 }\end{array}$ & $\begin{array}{l}\text { ATG12a } \\
\text { ATG12b }\end{array}$ & Interacting with HrpK1-Pto, HrpZ1-Pph, HrpZ1-Psy, Urf003, Urf012. & [52] \\
\hline AT3G62770 & ATG18a & $\begin{array}{c}\text { Atg18a mutants showed enhanced susceptibility to Alternaria } \\
\text { brassicicola, Botrytis cinerea, and showed reduced bacterial growth } \\
\text { rates when infected with Pto DC3000. } \\
\text { Phosphorylation modification of ATG18a suppresses } \\
\text { autophagosomes formation during Botrytis cinerea infection, which } \\
\text { results in compromised plant resistance against Botrytis cinerea. }\end{array}$ & {$[55,59,62]$} \\
\hline
\end{tabular}




\section{Roles of NPRs in Plant Immunity}

\subsection{The Structure of NPR1}

The transcription coactivator non-expressor of pathogenesis-related genes 1 (NPR1) is a key regulatory factor of SAR, which regulates most SA-responsive genes [30,63-66]. NPR1 contains an N-terminal BTB/POZ (Broad-Compex, Tramtrack, and BricaBrac/POxvirus and Zinc finger) domain, an ankyrin (ANK) repeat domain, a C-terminal transactivation domain, and a nuclear localization sequence [67-69]. NPR1 interacts with TGACG motifbinding factor (TGA) through ANK or BTB/POZ domain [70-72]. In the absence of SA, the C-terminal transactivation domain of NPR1 interacts with BTB/POZ domain, which inhibits NPR1 transcriptional coactivator function. The binding of SA to NPR1 leads to conformational changes of NPR1, it functions as a coactivator of gene transcription with the release of the $\mathrm{C}$-terminal transactivation domain from the N-terminal autoinhibitory domain [71,73]. A recent study provided a preliminary understanding of the structurefunction relationship of NPR proteins. The SA-binding core (SBC) consisting of amino acids $373-516$ in the NPR4 C-terminal domain was identified. Arabidopsis NPR4 and NPR1 share $38.1 \%$ sequence identity in their SBC region, they share the structural mechanism of $S A$ recognition. In addition, this study also found that conformational changes of NPR4 SBC could be induced by the binding of SA to NPR1 and NPR4 [74].

\subsection{NPR1 and Innate Immunity}

NPR1 is a master regulator of plant resistance to pathogen stress, which confers immunity through multiple transcription factors [75-77]. Research over the last 20 years has revealed the potential molecular mechanism of NPR1 in different cell states. Under normal growth conditions, NPR1 is present in the cytoplasm, stabilized by intermolecular disulfide bonds. Infection by pathogens results in the accumulation of SA and NPR1 oligomer-to-monomer reaction through SA-mediated redox changes in the cell, allowing NPR1 to migrate into the nucleus $[75,78,79]$. NPR1 indirectly activates $P R$ gene expression by interacting with TGA in the nucleus and plays an important role in regulating the PRs protein downstream $[63,80,81]$. The NPR1 in SA perception promotes TGAs transcriptional activity [82]. Recent studies have shown that NPR1 interacts with cyclin-dependent kinase 8 (CDK8) and enhanced disease susceptibility 1 (EDS1) to promote PR1 expression in the SA signaling pathway $[83,84]$.

A new study found that the formation of SA-induced NPR1 condensates (SINCs) is mediated by conserved cysteine clusters in intrinsic disorder regions (IDRs) of NPR1 protein. SINCs are rich in stress-responsive proteins, including NB-NLR receptors, oxidative and DNA damage-responsive proteins, and ubiquitination-related proteins. In addition, SINCs are required to form functional NPR1-Cullin 3 RING E3 ligase (CRL3) complex in the cytoplasm. NPR1-CRL3 complex can ubiquitinate and degrade EDS1 and some important ETI regulatory factors such as WRKY transcription factors, thereby promoting cell survival in ETI [85].

\subsection{NPR3/NPR4 and Plant Immunity}

In Arabidopsis, the NPR family consists of NPR1 and five NPR1-like genes, named NPR1like 2 (NPR2), NPR3, NPR4, BLADE-ON-PETIOLE2 (BOP2; NPR5), and BOP1 (NPR6) [86-89]. Each member of the NPR family contains a set of highly conserved cysteine residues that are thought to be involved in redox control [30]. It was confirmed that NPR1 and NPR3/NPR4 bind to SA and function as SA receptors, with NPR1 $\left(K_{d}=223.1 \pm 38.85 \mathrm{nM}\right)$ and NPR3 $\left(\mathrm{K}_{\mathrm{d}}=176.7 \pm 28.31 \mathrm{nM}\right)$ binding to SA with similar affinity. However, the affinity of NPR4 $\left(K_{d}=23.54 \pm 2.743 \mathrm{nM}\right)$ with SA is much higher [82]. Under normal conditions, NPR4 is a ligand of CRL3 substrate that can interact with NPR1, allowing proteasome to continuously ubiquitinate and degrade NPR1. At this time point, NPR3/NPR4 inhibits the expression of defense genes, thereby preventing an autoimmune response [90-92]. During SAR, as SA levels increase, SA binds to NPR4, induces the dissociation of NPR1 and NPR4, disrupts the NPR4-Cullin3 E3 ligase complex [90,92]. At this time point, the 
binding of SA to NPR3/NPR4 inhibits their transcriptional activity, while NPR1 in SA perception enhances its transcriptional activation, both of which are helpful in inducing the expression of defense genes [82]. In addition, studies have shown that NPR3 and NPR4 may promote PCD while NPR1 may inhibit PCD through resistance-avirulence (R-Avr) gene interaction [91]. Our previous study found that the expression of ATGs and the protein concentrations of ATG7 and ATG8a-PE were lower in npr3/npr4 mutants than in the wild-type. NPR3 and NPR4 may regulate the production of autophagosomes by promoting two ubiquitin-like conjugated systems [91].

\section{ATGs Participate in the Regulation of NPR1 Metabolism}

\subsection{Proteasome-Mediated NPR1 Degradation}

Pathogen infection causes accumulation of SA thus leads to post-translational modification of NPR1, allowing it to enter into the nucleus. NPR1 is recruited to Cullin3 (CUL3) for ubiquitination and subsequent degradation, this process requires phosphorylation of NPR1 at residues Ser11 and Ser15 [31,93-96]. The ubiquitination of NPR1 is a gradual process. Only when the polyubiquitination of NPR1 is enhanced by ubiquitin conjugation factor E4 (UBE4), it becomes the target of proteasome degradation [95]. Ubiquitin ligase activities are opposed by ubiquitin specific protease (UBP6/7). UBP6/7 are two proteasome-related deubiquitinases (DUBs) that increase NPR1 longevity [95]. In addition to UBP6/7, other DUBs may also play a role in regulating the expression of SA response genes, but their exact function is still unclear.

Some studies have found that the plant hormones abscisic acid (ABA) and SA antagonistically affect the level of NPR1 in cells. ABA promotes NPR1 degradation through the proteasome pathway mediated by the CUL3-NPR3/NPR4 complex, while SA protects NPR1 from ABA-induced degradation through phosphorylation [97-100]. AvrPtoB has a Ubox E3 ubiquitin ligase domain at the C-terminal and shows a weak interaction with NPR1 under uninduced conditions. SA promotes the interaction between AvrPtoB and NPR1, AvrPtoB mediates NPR1 ubiquitination by E3 ligase and mediates NPR1 degradation via the proteasome pathway [101].

\subsection{Relationship between ATGs and NPR1}

Studies have found that NPR1 regulates ATGs expression. NPR1 inhibited the mRNA expression of ATG1, ATG6, and ATG8a during the early HR induced by Psm ES4326/AvrRpt2 [61]. SA analog benzothiadiazole (BTH) was confirmed to induce autophagy through the NPR1-dependent signaling pathway, and NPR1, NPR3, and NPR4 are jointly involved in the regulation of autophagosomes [91]. In addition, several studies have shown that NPR1 affects the phenotype of autophagy-deficient mutants. NPR1 could accelerate the senescence or infection-induced accumulation of ubiquitinated proteins and endoplasmic reticulum stress in atg2 [54]. Yoshimoto et al. found that BTH could induce senescence and cell death in atg 5 mutants but could not induce senescence and cell death in atg 5 npr 1 double mutants, indicating that the cell death phenotype in atg5 mutants depended on NPR1 under SA induction [57]. Our previous study also found that ATG4 promoted NPR1 degradation by inhibiting the consumption of free SA [61]. In recent years, the relationship between ATGs and NPR1 has been gradually revealed (Table 2), but there are still many problems to be solved. 
Table 2. Relationship between ATGs and NPR1 in Arabidopsis.

\begin{tabular}{|c|c|c|c|}
\hline Gene & Protein & Relationship & References \\
\hline AT3G61960 & ATG1a & NPR1 inhibited the mRNA expression of ATG1 during Psm & \\
\hline AT3G53930 & ATG1b & ES4326/AvrRpt2 infections. & [61] \\
\hline AT3G19190 & ATG2 & $\begin{array}{c}\text { Accumulation of ubiquitinated proteins and increased ER stress in } \\
\text { older atg2 mutants which were suppressed by mutations in NPR1. } \\
\text { NPR1 somehow suppressed cell death in atg } 2 \text { mutants upon } \\
\text { pathogen infection. }\end{array}$ & [54] \\
\hline AT2G44140 & ATG4a & ATG4 inhibited the consumption of free SA and alleviated the & \\
\hline $\begin{array}{l}\text { A1 LG44140 } \\
\text { AT3G59950 }\end{array}$ & ATG4b & $\begin{array}{c}\text { degradation of NPR1 during Psm ES4326/AvrRpt2 induced } \\
\text { autophagy-dependent HR. }\end{array}$ & [61] \\
\hline AT5G17290 & ATG5 & $\begin{array}{l}\text { Pathogen-induced spread of chlorotic cell death and BTH } \\
\text { hypersensitivity in atg5 mutants required NPR1. }\end{array}$ & [57] \\
\hline AT3G61710 & ATG6 & $\begin{array}{c}\text { NPR1 inhibited the mRNA expression of ATG6 during Psm } \\
\text { ES4326/AvrRpt2 infections. }\end{array}$ & [61] \\
\hline AT4G21980 & ATG8a & $\begin{array}{c}\text { NPR1 inhibited the mRNA expression of ATG8a during Psm } \\
\text { ES4326/AvrRpt2 infections. }\end{array}$ & [61] \\
\hline
\end{tabular}

\section{Conclusions and Future Perspectives}

Autophagy-mediated degradation of proteins and organelles is essential for plant growth, development, maintenance of cell homeostasis, and immune response [34-37,44-51]. A series of ATGs co-located in the phagophore assembly site (PAS), initiate the process of autophagy. After that, the PI3Ks complex helps to form the nucleation of autophagy, followed by autophagosome membrane elongation [35,36,40-43,102]. NPR1 activity is regulated by phosphorylation, dephosphorylation, ubiquitination, and deubiquitination, and proteasome is involved in its degradation process (Figure 1). Nevertheless, there are still some questions to be answered, such as whether NPR1, NPR3, and NPR4 have the opposite effects on autophagy regulation and resistance to pathogen invasion? Do they co-repress the production of autophagosomes and the expression of EDS1? In recent years, the role of ATGs (ATG2, ATG5, ATG7, and ATG18a) in plant disease resistance has been gradually revealed (Table 1 ). In general, the accumulation of SA leads to the outbreak of ROS and further induces autophagy, while autophagy can reduce the production of ROS, thus forming a negative feedback regulation mechanism. ATGs, such as ATG6, can also regulate the occurrence of HR-PCD $[48,56,57,103,104]$. NPR1 has been proved to inhibit HR-PCD and affect the level of ROS in plants, while it is also affected by the level of ROS [30,91]. Based on this evidence, further research is needed to answer the following questions: Does the mutation or overexpression of ATGs affect NPR1 transformation from dimer to monomer? What are the effects of different ATGs on NPR1 entering the nucleus? What is the relationship between ATGs and NPR1 regulation of the HR-PCD response? Does autophagy and 26S proteasome co-regulate NPR1 turnover? An in-depth study of these issues will help us to understand how the autophagy pathway participates in the regulation of NPR1 metabolism. A recent study showed that the protein expression of NPR1 was significantly higher in $a \operatorname{tg} 4 a 4 b$ than that in wild type under normal condition and the expression of NPR1 in $a t g 4 a 4 b$ was higher than that in wild type under avrRpt2 treatment [61]. Based on the above finding and the relationships among ATG6, HRPCD, and NPR1, a hypothesis regarding ATGs participating in NPR1 metabolism was proposed (Figure 1): ATG6 may promote nuclear translocation of NPR1 by affecting the phosphorylation level of NPR1, while ATG4 may have the opposite effect. 


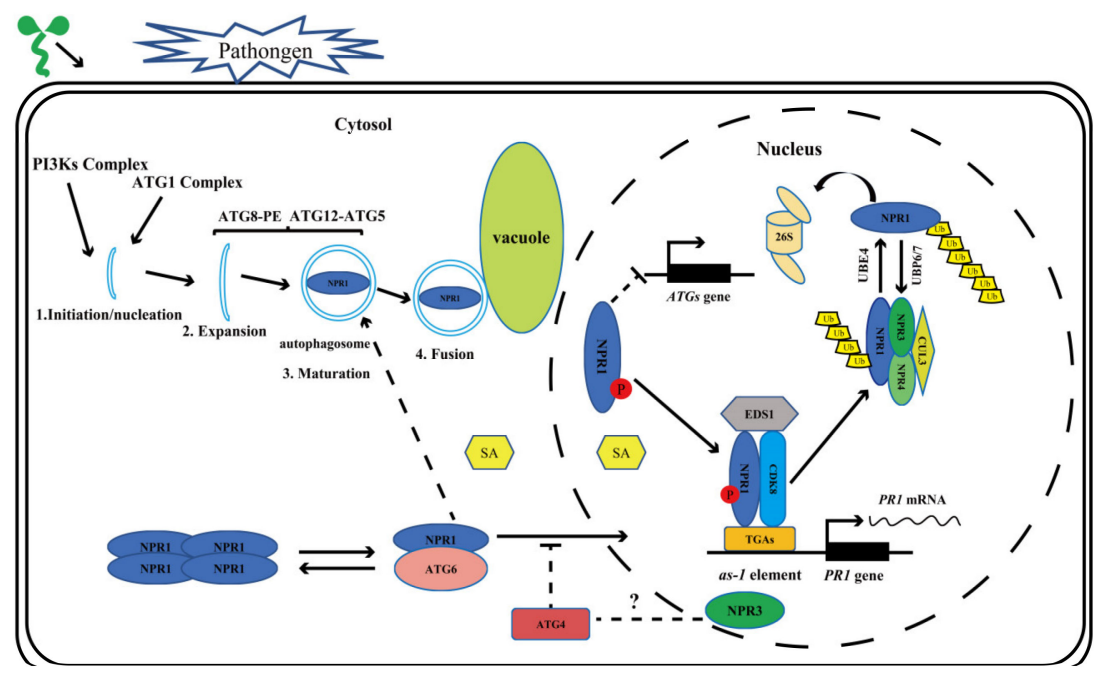

Figure 1. Pattern diagram of autophagy involved in NPR1 regulation in Arabidopsis. Autophagy pathway can be divided into four stages: initiation, expansion, maturation, and fusion. Normally, NPR1 exists in the cytoplasm as an oligomer. Upon pathogen infection, SA accumulates in the plant cell. NPR1 was phosphorylated and transferred from cytoplasm to nucleus. In the nucleus, NPR1 forms a protein complex with CDK8 and EDS1, promoting the expression of the PR1 gene. NPR1 is degraded by the $26 \mathrm{~S}$ proteasome complex through a series of polyubiquitination processes by CUL3 and UBE4, and its deubiquitination is mediated by UBP6 and UBP7, which are closely linked to 26S proteasome. It is reasonable to speculate that ATG6 may promote the entry of NPR1 into the nucleus, while ATG4 may have the opposite effect.

Author Contributions: The idea of the article was conceived by S.H. and B.Z.; structure of manuscript was designed by S.H. and B.Z.; tables and graphical work were created by S.H.; writing-review and editing, S.H., B.Z. and W.C. All authors have read and agreed to the published version of the manuscript.

Funding: This research was supported by the National Natural Science Foundation of China [grant number 31570256] and the Science and Technology project of Guangzhou (Grant No.201805010002).

Acknowledgments: We thank Wentao Huang (South China Normal University, China), Xue Li (South China Normal University, China) and Chengqian Zhou (Neuroscience Laboratory, Hugo Moser Research Institute at Kennedy Krieger, Baltimore MD 21205, USA).

Conflicts of Interest: The authors declare no conflict of interest.

\section{References}

1. Jones, J.; Dangl, J.L. The plant immune system. Nature 2006, 444, 323-329. [CrossRef]

2. Dangl, J.L.; Jones, J. Plant pathogens and integrated defence responses to infection. Nature 2001, 411, 826-833. [CrossRef] [PubMed]

3. Muthamilarasan, M.; Prasad, M. Plant innate immunity: An updated insight into defense mechanism. J. Biosci. 2013, 38, 433-449. [CrossRef] [PubMed]

4. Dodds, P.N.; Rathjen, J.P. Plant immunity: Towards an integrated view of plant-pathogen interactions. Nat. Rev. Genet. 2010, 11, 539-548. [CrossRef] [PubMed]

5. Gomez-Gomez, L.; Boller, T. Flagellin perception: A paradigm for innate immunity. Trends Plant Sci. 2002, 7, 251-256. [CrossRef]

6. Chinchilla, D.; Zipfel, C.; Robatzek, S.; Kemmerling, B.; Nurnberger, T.; Jones, J.D.; Felix, G.; Boller, T. A flagellin-induced complex of the receptor FLS2 and BAK1 initiates plant defence. Nature 2007, 448, 497-500. [CrossRef]

7. Nguyen, Q.M.; Iswanto, A.B.B.; Son, G.H.; Kim, S.H. Recent Advances in Effector-Triggered Immunity in Plants: New Pieces in the Puzzle Create a Different Paradigm. Int. J. Mol. Sci. 2021, 22, 4709. [CrossRef]

8. Chisholm, S.T.; Coaker, G.; Day, B.; Staskawicz, B.J. Host-microbe interactions: Shaping the evolution of the plant immune response-Sciencedirect. Cell 2006, 124, 803-814. [CrossRef] [PubMed]

9. Ngou, B.P.M.; Ahn, H.K.; Ding, P.; Redkar, A.; Brown, H.; Ma, Y.; Youles, M.; Tomlinson, L.; Jones, J.D.G. Estradiol-inducible AvrRps4 expression reveals distinct properties of TIR-NLR-mediated effector-triggered immunity. J. Exp. Bot. 2020, 71, $2186-2197$. [CrossRef] 
10. Kumar, J.; Ramlal, A.; Kumar, K.; Rani, A.; Mishra, V. Signaling Pathways and Downstream Effectors of Host Innate Immunity in Plants. Int. J. Mol. Sci. 2021, 22, 9022. [CrossRef] [PubMed]

11. Jebanathirajah, J.A.; Peri, S.; Pandey, A. Toll and interleukin-1 receptor (TIR) domain-containing proteins in plants: A genomic perspective. Trends Plant Sci. 2002, 7, 388-391. [CrossRef]

12. Monteiro, F.; Nishimura, M.T. Structural, Functional, and Genomic Diversity of Plant NLR Proteins: An Evolved Resource for Rational Engineering of Plant Immunity. Annu. Rev. Phytopathol. 2018, 56, 243-267. [CrossRef]

13. Hofius, D.; Schultz-Larsen, T.; Joensen, J.; Tsitsigiannis, D.I.; Petersen, N.H.T.; Mattsson, O.; Jørgensen, L.B.; Jones, J.D.G.; Mundy, J.; Petersen, M. Autophagic Components Contribute to Hypersensitive Cell Death in Arabidopsis. Cell 2009, 137, 773-783. [CrossRef]

14. Ve, T.; Williams, S.J.; Kobe, B. Structure and function of Toll/interleukin-1 receptor/resistance protein (TIR) domains. Apoptosis 2015, 20, 250-261. [CrossRef]

15. Sun, Y.; Zhu, Y.X.; Balint-Kurti, P.J.; Wang, G.F. Fine-Tuning Immunity: Players and Regulators for Plant NLRs. Trends Plant Sci. 2020, 25, 695-713. [CrossRef]

16. Ngou, B.P.M.; Ahn, H.K.; Ding, P.; Jones, J.D.G. Mutual potentiation of plant immunity by cell-surface and intracellular receptors. Nature 2021, 592, 110-115.

17. Yuan, M.; Jiang, Z.; Bi, G.; Nomura, K.; Liu, M.; He, S.Y.; Zhou, J.-M.; Xin, X.-F. Pattern-recognition receptors are required for NLR-mediated plant immunity. Nature 2021, 592, 105-109. [PubMed]

18. Yuan, M.; Ngou, B.P.M.; Ding, P.; Xin, X.F. PTI-ETI crosstalk: An integrative view of plant immunity. Curr. Opin. Plant Biol. 2021, 62, 102030. [CrossRef]

19. Ryals, J.A.; Neuenschwander, U.H.; Willits, M.G.; Molina, A.; Steiner, H.Y.; Hunt, M.D. Systemic acquired resistance. Plant Cell 1996, 8, 1809-1819. [CrossRef] [PubMed]

20. Shine, M.B.; Xiao, X.; Kachroo, P.; Kachroo, A. Signaling mechanisms underlying systemic acquired resistance to microbial pathogens. Plant Sci. 2019, 279, 81-86. [CrossRef] [PubMed]

21. Kohler, A.; Conrath, S.U. Benzothiadiazole-Induced Priming for Potentiated Responses to Pathogen Infection, Wounding, and Infiltration of Water into Leaves Requires the NPR1/NIM1 Gene in Arabidopsis. Plant Physiol. 2002, 128, 1046-1056. [CrossRef]

22. Gao, Q.M.; Kachroo, A.; Kachroo, P. Chemical inducers of systemic immunity in plants. J. Exp. Bot. 2014, 65, 1849-1855. [CrossRef]

23. Gao, Q.M.; Zhu, S.; Kachroo, P.; Kachroo, A. Signal regulators of systemic acquired resistance. Front. Plant Sci. 2015, 6, 228. [CrossRef] [PubMed]

24. Chen, L.; Wang, W.S.; Wang, T.; Meng, X.F.; Chen, T.T.; Huang, X.X.; Li, Y.J.; Hou, B.K. Methyl Salicylate Glucosylation Regulates Plant Defense Signaling and Systemic Acquired Resistance. Plant Physiol. 2019, 180, 2167-2181. [CrossRef] [PubMed]

25. Pieterse, C.M.J.; Van der Does, D.; Zamioudis, C.; Leon-Reyes, A.; Van Wees, S.C.M. Hormonal Modulation of Plant Immunity. Annu. Rev. Cell Dev. Biol. 2012, 28, 489-521. [CrossRef]

26. Kiefer, I.W.; Slusarenko, A.J. The pattern of systemic acquired resistance induction within the Arabidopsis rosette in relation to the pattern of translocation. Plant Physiol. 2003, 132, 840-847. [CrossRef] [PubMed]

27. Bernsdorff, F.; Doring, A.C.; Gruner, K.; Schuck, S.; Brautigam, A.; Zeier, J. Pipecolic Acid Orchestrates Plant Systemic Acquired Resistance and Defense Priming via Salicylic Acid-Dependent and -Independent Pathways. Plant Cell 2016, 28, 102-129. [CrossRef]

28. Tian, H.; Zhang, Y. The Emergence of a Mobile Signal for Systemic Acquired Resistance. Plant Cell 2019, 31, 1414-1415. [CrossRef]

29. Van Loon, L.C.; Rep, M.; Pieterse, C.M. Significance of inducible defense-related proteins in infected plants. Annu. Rev. Phytopathol. 2006, 44, 135-162. [CrossRef]

30. Mou, Z.; Fan, W.H.; Dong, X.N. Inducers of plant systemic acquired resistance regulate NPR1 function through redox changes. Cell 2003, 113, 935-944. [CrossRef]

31. Spoel, S.H.; Mou, Z.L.; Tada, Y.; Spivey, N.W.; Genschik, P.; Dong, X.N.A. Proteasome-Mediated Turnover of the Transcription Coactivator NPR1 Plays Dual Roles in Regulating Plant Immunity. Cell 2009, 137, 860-872. [CrossRef]

32. Wenig, M.; Ghirardo, A.; Sales, J.H.; Pabst, E.S.; Breitenbach, H.H.; Antritter, F.; Weber, B.; Lange, B.; Lenk, M.; Cameron, R.K.; et al. Systemic acquired resistance networks amplify airborne defense cues. Nat. Commun. 2019, 10, 3813. [CrossRef]

33. Riedlmeier, M.; Ghirardo, A.; Wenig, M.; Knappe, C.; Koch, K.; Georgii, E.; Dey, S.; Parker, J.E.; Schnitzler, J.P.; Vlot, A.C. Monoterpenes Support Systemic Acquired Resistance within and between Plants. Plant Cell 2017, 29, 1440-1459. [CrossRef]

34. Michaeli, S.; Galili, G. Degradation of organelles or specific organelle components via selective autophagy in plant cells. Int. J. Mol. Sci. 2014, 15, 7624-7638. [CrossRef]

35. Rubinsztein, D.C.; Shpilka, T.; Elazar, Z. Mechanisms of autophagosome biogenesis. Curr. Biol. 2012, 22, 29-34. [CrossRef] [PubMed]

36. Weidberg, H.; Shvets, E.; Elazar, Z. Biogenesis and cargo selectivity of autophagosomes. Annu. Rev. Biochem. 2011, 80, 125-156. [CrossRef]

37. Marshall, R.S.; Vierstra, R.D. Autophagy: The Master of Bulk and Selective Recycling. Annu. Rev. Plant Biol. 2018, 69, 173-208. [CrossRef]

38. Mizushima, N.; Yoshimori, T.; Ohsumi, Y. The role of Atg proteins in autophagosome formation. Annu. Rev. Cell Dev. Biol. 2011, 27, 107-132. [CrossRef] [PubMed]

39. Zhang, H.Z. Prediction of the Function of Autophagy-Related Genes (ATGs) in Development and Abiotic Stress Based on Expression Profiling in Arabidopsis. Jiyinzuxue Yu Yingyong Shengwuxue (Genom. Appl. Biol.) 2020, 39, $2671-2682$. 
40. Shibutani, S.T.; Yoshimori, T. A current perspective of autophagosome biogenesis. Cell Res. 2014, 24, 58-68. [CrossRef] [PubMed]

41. Suzuki, K.; Kirisako, T.; Kamada, Y.; Mizushima, N.; Noda, T.; Ohsumi, Y. The pre-autophagosomal structure organized by concerted functions of APG genes is essential for autophagosome formation. EMBO J 2001, 20, 5971-5981. [CrossRef] [PubMed]

42. Geng, J.; Klionsky, D.J. The Atg8 and Atg12 ubiquitin-like conjugation systems in macroautophagy. 'Protein modifications: Beyond the usual suspects' review series. EMBO Rep. 2008, 9, 859-864. [CrossRef]

43. Tanida, I. Autophagy basics. Microbiol. Immunol. 2011, 55, 1-11. [CrossRef] [PubMed]

44. Guan, B.; Lin, Z.; Liu, D.; Li, C.; Zhou, Z.; Mei, F.; Li, J.; Deng, X. Effect of Waterlogging-Induced Autophagy on Programmed Cell Death in Arabidopsis Roots. Front. Plant Sci. 2019, 10, 468. [CrossRef] [PubMed]

45. Bassham, D.C.; Laporte, M.; Marty, F.; Moriyasu, Y.; Ohsumi, Y.; Olsen, L.J.; Yoshimoto, K. Autophagy in development and stress responses of plants. Autophagy 2006, 2, 2-11. [CrossRef]

46. Liu, Y.; Bassham, D.C. Autophagy: Pathways for self-eating in plant cells. Annu. Rev. Plant Biol. 2012, 63, 215-237. [CrossRef]

47. Zhou, J.; Yu, J.Q.; Chen, Z. The perplexing role of autophagy in plant innate immune responses. Mol. Plant Pathol. 2014, 15, 637-645. [CrossRef]

48. Gou, W.; Li, X.; Guo, S.; Liu, Y.; Li, F.; Xie, Q. Autophagy in Plant: A New Orchestrator in the Regulation of the Phytohormones Homeostasis. Int. J. Mol. Sci. 2019, 20, 2900. [CrossRef] [PubMed]

49. Qi, H.; Xia, F.N.; Xiao, S. Autophagy in plants: Physiological roles and post-translational regulation. J. Integr. Plant Biol. 2021, 63, 161-179. [CrossRef]

50. Talbot, N.J.; Kershaw, M.J. The emerging role of autophagy in plant pathogen attack and host defence. Curr. Opin. Plant Biol. 2009, 12, 444-450. [CrossRef]

51. Yoshimoto, K.; Takano, Y.; Sakai, Y. Autophagy in plants and phytopathogens. FEBS Lett. 2010, 584, 1350-1358. [CrossRef] [PubMed]

52. Lal, N.K.; Thanasuwat, B.; Chan, B.; Dinesh-Kumar, S.P. Pathogens manipulate host autophagy through injected effector proteins. Autophagy 2020, 16, 2301-2302. [CrossRef] [PubMed]

53. Wang, Y.; Nishimura, M.T.; Zhao, T.; Tang, D. ATG2, an autophagy-related protein, negatively affects powdery mildew resistance and mildew-induced cell death in Arabidopsis. Plant J. 2011, 68, 74-87. [CrossRef] [PubMed]

54. Munch, D.; Rodriguez, E.; Bressendorff, S.; Park, O.K.; Hofius, D.; Petersen, M. Autophagy deficiency leads to accumulation of ubiquitinated proteins, ER stress, and cell death in Arabidopsis. Autophagy 2014, 10, 1579-1587. [CrossRef]

55. Rigault, M.; Citerne, S.; Masclaux-Daubresse, C.; Dellagi, A. Salicylic acid is a key player of Arabidopsis autophagy mutant susceptibility to the necrotrophic bacterium Dickeya dadantii. Sci. Rep. 2021, 11, 3624. [CrossRef]

56. Patel, S.; Dinesh-Kumar, S.P. Arabidopsis ATG6 is required to limit the pathogen-associated cell death response. Autophagy 2008, 4, 20-27. [CrossRef] [PubMed]

57. Yoshimoto, K.; Jikumaru, Y.; Kamiya, Y.; Kusano, M.; Consonni, C.; Panstruga, R.; Ohsumi, Y.; Shirasu, K. Autophagy negatively regulates cell death by controlling NPR1-dependent salicylic acid signaling during senescence and the innate immune response in Arabidopsis. Plant Cell 2009, 21, 2914-2927. [CrossRef]

58. Lai, Z.; Wang, F.; Zheng, Z.; Fan, B.; Chen, Z. A critical role of autophagy in plant resistance to necrotrophic fungal pathogens. Plant J. 2011, 66, 953-968. [CrossRef]

59. Lenz, H.D.; Vierstra, R.D.; Nurnberger, T.; Gust, A.A. ATG7 contributes to plant basal immunity towards fungal infection. Plant Signal Behav. 2011, 6, 1040-1042. [CrossRef]

60. Dong, J.; Chen, W. The role of autophagy in chloroplast degradation and chlorophagy in immune defenses during Pst DC3000 (AvrRps4) infection. PLoS ONE 2013, 8, e73091. [CrossRef]

61. Gong, W.; Li, B.; Zhang, B.; Chen, W. ATG4 Mediated Psm ES4326/AvrRpt2-Induced Autophagy Dependent on Salicylic Acid in Arabidopsis Thaliana. Int. J. Mol. Sci. 2020, 21, 5147. [CrossRef] [PubMed]

62. Zhang, B.; Shao, L.; Wang, J.; Zhang, Y.; Guo, X.; Peng, Y.; Cao, Y.; Lai, Z. Phosphorylation of ATG18a by BAK1 suppresses autophagy and attenuates plant resistance against necrotrophic pathogens. Autophagy 2020, 17, 2093-2110. [CrossRef]

63. Zhang, Y.; Li, X. Salicylic acid: Biosynthesis, perception, and contributions to plant immunity. Curr. Opin. Plant Biol. 2019, 50, 29-36. [CrossRef] [PubMed]

64. Chen, J.; Zhang, J.; Kong, M.; Freeman, A.; Chen, H.; Liu, F. More stories to tell: Nonexpressor of pathogenesis-related Genes1, a salicylic acid receptor. Plant Cell Environ. 2021, 44, 1716-1727. [CrossRef]

65. Cao, H.; Li, X.; Dong, X. Generation of broad-spectrum disease resistance by overexpression of an essential regulatory gene in systemic acquired resistance. Proc. Natl. Acad. Sci. USA 1998, 95, 6531-6536. [CrossRef] [PubMed]

66. Cao, H. Characterization of an Arabidopsis Mutant That Is Nonresponsive to Inducers of Systemic Acquired Resistance. Plant Cell Online 1994, 6, 1583-1592. [CrossRef]

67. Kuai, X.; MacLeod, B.J.; Despres, C. Integrating data on the Arabidopsis NPR1/NPR3/NPR4 salicylic acid receptors; a differentiating argument. Front. Plant Sci. 2015, 6, 235. [CrossRef] [PubMed]

68. Cao, H.; Glazebrook, J.; Clarke, J.D.; Volko, S.; Dong, X. The Arabidopsis NPR1 gene that controls systemic acquired resistance encodes a novel protein containing ankyrin repeats. Cell 1997, 88, 57-63. [CrossRef]

69. Ryals, J.; Weymann, K.; Lawton, K.; Friedrich, L.; Ellis, D.; Steiner, H.Y.; Johnson, J.; Delaney, T.P.; Jesse, T.; Vos, P.; et al. The Arabidopsis NIM1 protein shows homology to the mammalian transcription factor inhibitor I kappa B. Plant Cell 1997, 9, 425-439. [CrossRef] [PubMed] 
70. Liu, L.L. Advances of the Mechanism and Function of Disease Resistance Regulated by NPR1 in Plants. China Cotton 2020, 47, 1-6.

71. Rochon, A.; Boyle, P.; Wignes, T.; Fobert, P.R.; Despres, C. The coactivator function of Arabidopsis NPR1 requires the core of its BTB/POZ domain and the oxidation of C-terminal cysteines. Plant Cell 2006, 18, 3670-3685. [CrossRef]

72. Mosavi, L.K.; Cammett, T.J.; Desrosiers, D.C.; Peng, Z.Y. The ankyrin repeat as molecular architecture for protein recognition. Protein Sci. 2004, 13, 1435-1448. [CrossRef]

73. Wu, Y.; Zhang, D.; Chu, J.Y.; Boyle, P.; Wang, Y.; Brindle, I.D.; De Luca, V.; Despres, C. The Arabidopsis NPR1 Protein Is a Receptor for the Plant Defense Hormone Salicylic Acid. Cell Rep. 2012, 1, 639-647. [CrossRef] [PubMed]

74. Wang, W.; Withers, J.; Li, H.; Zwack, P.J.; Rusnac, D.V.; Shi, H.; Liu, L.; Yan, S.; Hinds, T.R.; Guttman, M.; et al. Structural basis of salicylic acid perception by Arabidopsis NPR proteins. Nature 2020, 586, 311-316. [CrossRef]

75. Sun, Y.L.; Detchemendy, T.W.; Pajerowska-Mukhtar, K.M.; Mukhtar, M.S. NPR1 in JazzSet with Pathogen Effectors. Trends Plant Sci. 2018, 23, 469-472. [CrossRef] [PubMed]

76. Dong, X. NPR1, all things considered. Curr. Opin. Plant Biol. 2004, 7, 547-552. [CrossRef] [PubMed]

77. Li, M.; Chen, H.; Chen, J.; Chang, M.; Palmer, I.A.; Gassmann, W.; Liu, F.; Fu, Z.Q. TCP Transcription Factors Interact with NPR1 and Contribute Redundantly to Systemic Acquired Resistance. Front. Plant Sci. 2018, 9, 1153. [CrossRef] [PubMed]

78. Pajerowska-Mukhtar, K.M.; Emerine, D.K.; Mukhtar, M.S. Tell me more: Roles of NPRs in plant immunity. Trends Plant Sci. 2013, 18, 402-411. [CrossRef]

79. Kinkema, M.; Fan, W.H.; Dong, X.N. Nuclear localization of NPR1 is required for activation of PR gene expression. Plant Cell 2000, 12, 2339-2350. [CrossRef]

80. Zhang, Y.; Fan, W.; Kinkema, M.; Li, X.; Dong, X. Interaction of NPR1 with basic leucine zipper protein transcription factors that bind sequences required for salicylic acid induction of the PR-1 gene. Proc. Natl. Acad. Sci. USA 1999, 96, 6523-6528. [CrossRef]

81. Despres, C.; DeLong, C.; Glaze, S.; Liu, E.; Fobert, P.R. The Arabidopsis NPR1/NIM1 protein enhances the DNA binding activity of a subgroup of the TGA family of bZIP transcription factors. Plant Cell 2000, 12, 279-290. [CrossRef] [PubMed]

82. Ding, Y.; Sun, T.; Ao, K.; Peng, Y.; Zhang, Y.; Li, X.; Zhang, Y. Opposite Roles of Salicylic Acid Receptors NPR1 and NPR3/NPR4 in Transcriptional Regulation of Plant Immunity. Cell 2018, 173, 1454-1467. [CrossRef]

83. Chen, H.; Li, M.; Qi, G.; Zhao, M.; Liu, L.; Zhang, J.; Chen, G.; Wang, D.; Liu, F.; Fu, Z.Q. Two interacting transcriptional coactivators cooperatively control plant immune responses. bioRxiv 2021. [CrossRef]

84. Chen, J.; Mohan, R.; Zhang, Y.; Li, M.; Chen, H.; Palmer, I.A.; Chang, M.; Qi, G.; Spoel, S.H.; Mengiste, T.; et al. NPR1 Promotes Its Own and Target Gene Expression in Plant Defense by Recruiting CDK8. Plant Physiol. 2019, 181, 289-304. [CrossRef] [PubMed]

85. Zavaliev, R.; Mohan, R.; Chen, T.; Dong, X. Formation of NPR1 Condensates Promotes Cell Survival during the Plant Immune Response. Cell 2020, 182, 1093-1108. [CrossRef]

86. Shi, Z.; Maximova, S.; Liu, Y.; Verica, J.; Guiltinan, M.J. The Salicylic Acid Receptor NPR3 Is a Negative Regulator of the Transcriptional Defense Response during Early Flower Development in Arabidopsis. Mol. Plant 2013, 6, 802-816. [CrossRef]

87. Hepworth, S.R.; Zhang, Y.L.; McKim, S.; Li, X.; Haughn, G. BLADE-ON-PETIOLE-dependent signaling controls leaf and floral patterning in Arabidopsis. Plant Cell 2005, 17, 1434-1448. [CrossRef] [PubMed]

88. Liu, G.; Holub, E.B.; Alonso, J.M.; Ecker, J.R.; Fobert, P.R. An Arabidopsis NPR1-like gene, NPR4, is required for disease resistance. Plant J. 2005, 41, 304-318. [CrossRef] [PubMed]

89. Norberg, M.; Holmlund, M.; Nilsson, O. The BLADE ON PETIOLE genes act redundantly to control the growth and development of lateral organs. Development 2005, 132, 2203-2213. [CrossRef]

90. Fu, Z.Q.; Yan, S.P.; Saleh, A.; Wang, W.; Ruble, J.; Oka, N.; Mohan, R.; Spoel, S.H.; Tada, Y.; Zheng, N.; et al. NPR3 and NPR4 are receptors for the immune signal salicylic acid in plants. Nature 2012, 486, 228-232. [CrossRef]

91. Wang, X.; Gao, Y.; Yan, Q.; Chen, W. Salicylic acid promotes autophagy via NPR3 and NPR4 in Arabidopsis senescence and innate immune response. Acta Physiol. Plant. 2016, 38, 1-12. [CrossRef]

92. Li, X.; Zhang, Y. A structural view of salicylic acid perception. Nat. Plants 2020, 6, 1197-1198. [CrossRef]

93. Furniss, J.J.; Spoel, S.H. Cullin-RING ubiquitin ligases in salicylic acid-mediated plant immune signaling. Front. Plant Sci. 2015, 6, 154. [CrossRef] [PubMed]

94. Trujillo, M.; Shirasu, K. Ubiquitination in plant immunity. Curr. Opin. Plant Biol. 2010, 13, 402-408. [CrossRef] [PubMed]

95. Skelly, M.J.; Furniss, J.J.; Grey, H.; Wong, K.W.; Spoel, S.H. Dynamic ubiquitination determines transcriptional activity of the plant immune coactivator NPR1. eLife 2019, 8, e47005. [CrossRef]

96. Withers, J.; Dong, X. Posttranslational Modifications of NPR1: A Single Protein Playing Multiple Roles in Plant Immunity and Physiology. PLoS Pathog. 2016, 12, e1005707. [CrossRef] [PubMed]

97. Ding, Y.; Dommel, M.; Mou, Z. Abscisic acid promotes proteasome-mediated degradation of the transcription coactivator NPR1 in Arabidopsis thaliana. Plant J. 2016, 86, 20-34. [CrossRef]

98. Westermarck, J. Regulation of transcription factor function by targeted protein degradation: An overview focusing on p35, c-Myc, and c-Jun. Methods Mol. Biol. 2010, 64, 31-36.

99. Peng, Z.; Hu, Y.; Zhang, J.; Huguet-Tapia, J.C.; Block, A.K.; Park, S.; Sapkota, S.; Liu, Z.; Liu, S.; White, F.F. Xanthomonas translucens commandeers the host rate-limiting step in ABA biosynthesis for disease susceptibility. Proc. Natl. Acad. Sci. USA 2019, 116, 20938-20946. [CrossRef]

100. Spence, C.A.; Lakshmanan, V.; Donofrio, N.; Bais, H.P. Crucial Roles of Abscisic Acid Biogenesis in Virulence of Rice Blast Fungus Magnaporthe oryzae. Front. Plant Sci. 2015, 6, 1082. [CrossRef] 
101. Chen, H.; Chen, J.; Li, M.; Chang, M.; Xu, K.M.; Shang, Z.H.; Zhao, Y.; Palmer, I.; Zhang, Y.Q.; McGill, J.; et al. A Bacterial Type III Effector Targets the Master Regulator of Salicylic Acid Signaling, NPR1, to Subvert Plant Immunity. Cell Host Microbe 2017, 22, 777-788. [CrossRef] [PubMed]

102. Lamb, C.A.; Yoshimori, T.; Tooze, S.A. The autophagosome: Origins unknown, biogenesis complex. Nat. Rev. Mol. Cell Biol. 2013, 14, 759-774. [CrossRef] [PubMed]

103. Signorelli, S.; Tarkowski, L.P.; Van den Ende, W.; Bassham, D.C. Linking Autophagy to Abiotic and Biotic Stress Responses. Trends Plant Sci. 2019, 24, 413-430. [CrossRef] [PubMed]

104. Patel, S.; Caplan, J.; Dinesh-Kumar, S.P. Autophagy in the control of programmed cell death. Curr. Opin. Plant Biol. 2006, 9, 391-396. [CrossRef] [PubMed] 